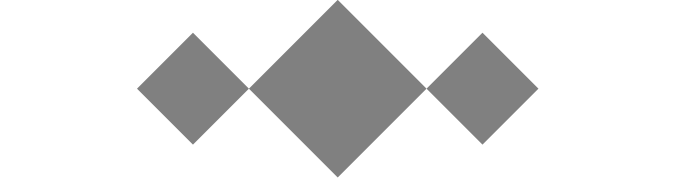

新しい偏光顕微鏡 (Pol-Scope) - 兴の原理と応用 -

産業技術総合研究所脳神経情報研究部門*, 科学技術振興機構さきがけ研究 21 「認識と形成」領域** 加藤 薰*,**, 吉田史子*

\section{1.はじめに}

新しい偏光顕微鏡 (Pol-Scope) ${ }^{1), 2)}$ は, R. Oldenbour か開発した顕微鏡システムである. 生体試料のわずか な複屈折を 2 次元計測し, マップとして表示し, 生体試 料内部の結晶性構造を可視化する. この観察法は, きち んと観察条件を決めれば, 再現性の良い結果が比較的 容易に得られる. この小文では, Pol-Scopeの原理と応用 について述べる.

\section{Pol-Scope で観察した細胞}

Fig.1 は筆者の研究室のPol-Scope で観察したニュー ロブラストーマ (神経芽腫細胞) である. 成長円錐と光

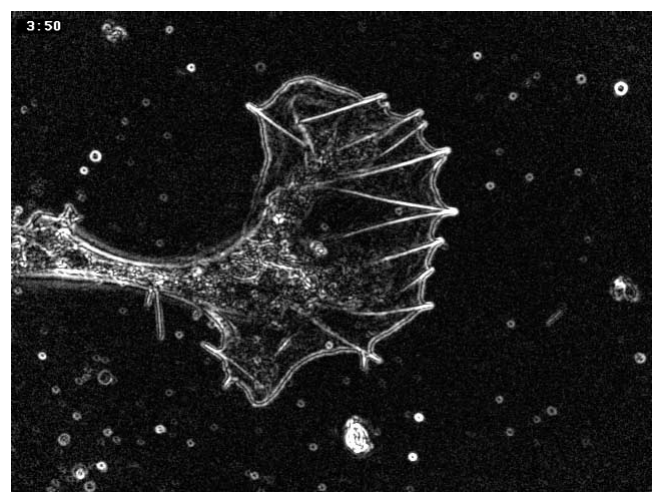

Fig.1 A growth cone revealed with a Pol-Scope. ( 電子ジ ヤーナルに動画あり)
の内部のアクチン束が綺麗に無染色で観察できる (webサイトのmovie も参照).

現在の最も一般的なアクチン束の観察法である蛍光 観察法と比較して, 同等の精度でアクチン束を観察で きる $(\text { Fig.2 })^{3)}$.さらに, Pol-Scope では

1) 試料の染色が不要で, 退色の心配がない.

2) 検出能が高い. (分解能は通常の光学顕微鏡と同じ)

3 ) 定量性をもつ (タンパク質の䋊維の定量ができる)

(Fig.3).

という利点がある. 短所は, 試料自体の光学条件を良く する工夫が必要なことである.

観察対象となる生物試料は, 1. 細胞骨格, 2. 染色体の DNA, 3. 膜構造 (細胞膜, ミトコンドリア, 各種小胞, 小 胞体) などである.いずれも複屈折性という分光学的性 質をもつ試料である.
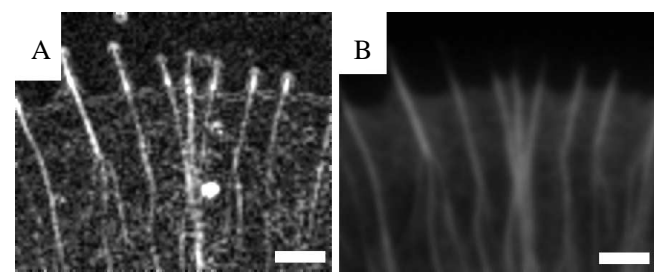

Fig.2 Comparison between pictures taken with a fluorescence microscope and a Pol-Scope. A : Pol-Scope, B : Rodamine-phalloidin. Bars : $2 \mu \mathrm{m}$. ( 文献3より許可 を得て複製)

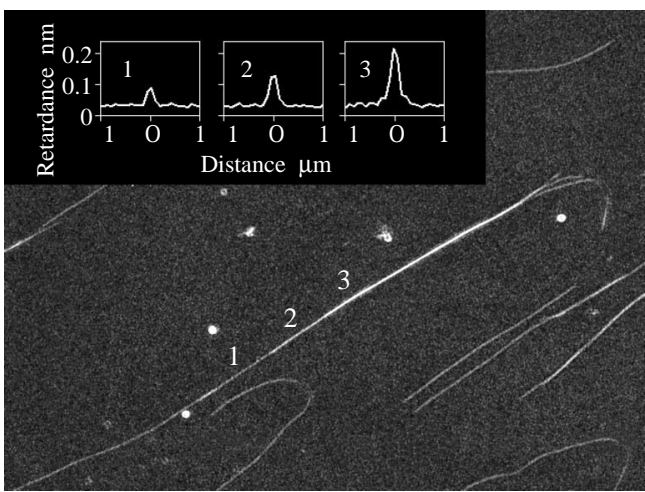

Fig.3 Estimate of number of microtubules with a Pol-Scope. （文献11より許可を得て複製）

\title{
Application of a Pol-Scope on Cell Physiology
}

Kaoru Katoh*,** and Fumiko Yoshida*

* Neuroscience Research Institute, National Institute of Advanced Industrial Science and Technology (AIST)

** PRESTO, JST 
3 . 複屈折*とは何か (複屈折はリタデーション* と slow axis orientationで表される)

「複屈折」4)-8) (教養の物理でも扱われる物理的性質 だが, 生物学分野ではあまり馴染みがないので, 簡単に 触れる.

方解石のような分子の並びに異方性がある結晶は, 「試料に入射する偏光波の振動方向により, 屈折率が異 なる性質」を示す. これを複屈折という. 屈折率 $n$ と媒 質中の光速度 $v$ の関係,

$$
n=c / v\left(c \text { : 真空中の光速度, 約 } 3.0 \times 10^{5} \mathrm{~km} / \mathrm{s}\right)
$$

を用いて,「媒質中の光速度 $v 」 て ゙$ 複屈折を表現できる. この場合, 複屈折は「試料中を進む偏光波の振動方向に より光速度 $(v)$ が異なる性質」となる.

次に, 複屈折性の試料に入射した単色光の光波の振る 舞いを考えてみよう. 試料の界面で, 光波は振動方向か直 交するo波 (ordinary ray (常光線)) とe波 (extraordinary ray (異常光線)) とに分かれる. 複屈折性の試料中では e 波とo 波で伝播速度が異なるため, 試料を透過したe 波とo波の間には, 位相のズレが生じる.この波とo 波 の位相のズレに相当する光路長差が・リタデーション (birefringence retardation または retardance)”*2であり, 光速度が最小となる光の振動方向が slow axis orientation (またはアズムス角 (azimuth angle))”である.この2つ の物理量で複屈折は決まる.

リタデーションと slow axis orientationは複屈折性の 試料の分子の並びの情報を与える.たとえば, 繊維状夕 ンパク質の束では,リタデーションは束に含まれる緎 維数に比例し, slow axis orientationはタンパク質の䋐維 の方向に平行になる. つまり, タンパク質の纎維束中の 纎維の本数と方向を見積れる (Fig.3).

\section{4 .Pol-Scopeの動作原理}

Pol-Scope ${ }^{1), 2)}$ は, 従来の偏光顕微鏡 ${ }^{5), 6)}$ の上位互換 である (Fig.4). 従来型との光学系の違いは, 次の2点

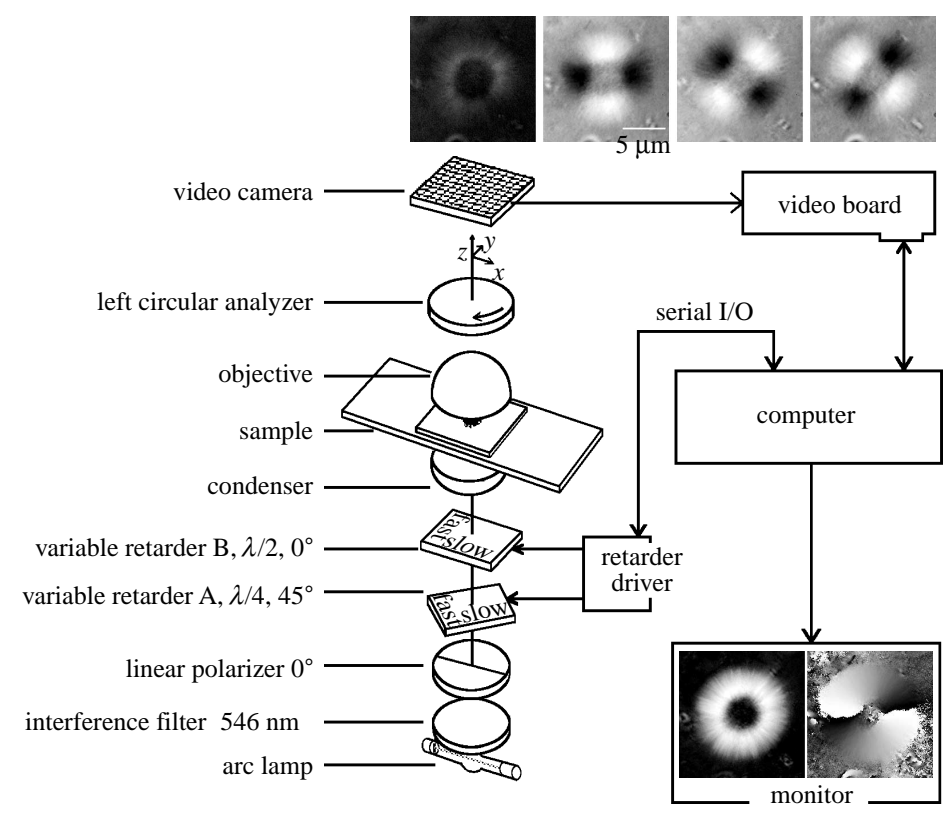

Fig.4 Optical setup of a Pol-Scope. ( 文献 1 より許可を得て複製)

*1 方解石に透かして物体を見ると, 界面で生じた $2 つ の$ 屈折光 (o 波と $\mathrm{e}$ 波) のために, 物体の像が二重に見える. こ の現象は, 複屈折の例として, よく取り上げられる. 生物試料では, 複屈折はきわめて小さく, o 波と $\mathrm{e}$ 波の屈折率 の差がわずかで, 方解石のように像が二重に見えることはない.

*2 単色光が複屈折性の試料を透過した後に生じるo 波と $\mathrm{e}$ 波の位相差 $(\Delta)$ は,

$$
\Delta=2 \pi d\left(n_{\mathrm{e}}-n_{\mathrm{o}}\right) / \lambda
$$

(ただし $d:$ 試料の厚さ, $n_{\mathrm{e}}: \mathrm{e}$ 波に対する屈折率, $n_{\mathrm{o}}: \mathrm{o}$ 波に対する屈折率, $\lambda:$ 光の波長)

となる. 上式の“ $d\left(n_{\mathrm{e}}-n_{\mathrm{o}}\right)$ ” はサンプル自体の性質できまる物理量で, リタデーション (birefringence retardation またはretardance) とよばれる.リタデーションは試料中のe 波とo 波の「相対的な光路長の差 (relative optical path length difference)」を表している. 
である. 1) 電気制御のコンペンセータ(複屈折性の液 晶板).2) 検光子 (左円偏光板).

このうち複屈折性の液晶板が重要である. この液晶に 与える電圧をコンピュータで制御し, 楕円率と振動方 向の異なる偏光波をつくりだし, 試料を照明する. 通常 の動作では, 円偏光と, 楕円率が同じで振動方向が45 度 ずつ異なる 3 種類の楕円偏光て試料を照明し, 各々の条 件下で記録した画像 (4枚) を用いて,リタデーション と slow axis orientation を各画素ごとに近似計算する.計 算式は, Oldenbourg と Meiか導いた. 計算誤差はリタデ ーションで2 \%, slow axis orientation で0.5 \%である. 実 際の計算法は紙面の都合で省く.

\section{Pol-Scopeの導入}

\section{1 システムをインストールする顕微鏡}

Pol-Scope は, 通常の顕微鏡 (メーカーは問わない) にインストールする. 光路のホコリ, ゴミ, カビを嫌うの で, 常に清浄な状態に保つ.

対物レンズは標準品でも, かなりの精度で動作する. ただし, 品質維持のため注意深い丁寧な取り扱いが重 要である ${ }^{8)}$.たとえば, $10 \mathrm{~cm}$ ほどの高さから机上に落と したり, 恒温ステージで局所的に熱を加えると, 偏光特 性か落ち, 徐々に精度が出なくなる.

\section{2 実際の設置}

液晶装置は2枚の液晶 (可変コンペンセータ) に直 線偏光子を組み込んだ構造をしており, 表裏と方位が ある. 正しい方向に設置する. 左円偏光子も同樣に注意 深く設置する. 液晶装置と偏光子の位置関係は, 顕微鏡 の検出能に関係するので重要である. 現在の市販品で は,マニュアルどおりに図示された位置に取り付けれ ばよい.

コンピュータは液晶を制御し, 照明光の偏光状態を 変えつつ原画像を取得し, リタデーションと slow axis orientation を算出し, 表示する. 一般の使い方ならソフ トウエアも含めてマニュアルどおりである.

\section{Pol-Scopeの操作}

\section{1 生体試料の準備}

Pol-Scope の観察では試料の光学条件は重要である. 以下注意すべきことを書く

a. カバーガラス :

対物レンズにあったカバーガラスを使用する.一般に は, No.1s (No.1ではない!) を用いる. 高開口数の油 浸レンズでの観察では, カバーガラスの厚さは画像に 重大な影響を及ばす ${ }^{9)}$. b. ガラス表面のコート :

カバーガラスの表面に細胞を培養するとき, ガラス表 面をコートする. コートはできるだけ低分子量のもの で行う. ラミニンのような大きな分子を使うと, コート に用いた分子の固まり自体が観察され, 細胞内の分子 など,とても見ることができない.

c. 細胞の選択 :

観察試料の厚さも重要である.できるだけ透明度の高 い試料を選ぶか, あるいはつくる工夫が必要である. 我々は, 成長円錐のlamellipodia の部分が薄く広がった ものを選択した. また, 上皮組織をガラスと半透膜の間 に挟んて培養し, きわめてわずかな隙間に入り込んで 薄く広がった細胞のみを観察に使ったこともある. 光 学顕微鏡の限界に近い試料を観察するには, 光学条件 がよい試料をつくる工夫が必要である.

6.2 顕微鏡の動作 (原画像の記録と birefringence retardation map の作成)

光学条件の良い試料を準備し, ステージ上に据えると 検鏡の始まりである. 調整は通常の顕微鏡と同樣である. 1. ケーラー照明※にする.

2. レボルバーの対物レンズの芯出し用ネジを調節して, 対物レンズの光軸を調節する.

3. 観察する細胞を選択する.

4. 原画像を記録し, 記録後, コンピュータ上で処理を行 いリタデーションのマップを作成する.

(詳しい動作は付属のマニュアルに詳しく書かれて (るので略す).

上記の操作で, ケーラー照明がすべての基本である. ケーラー照明の条件から多少ずれると, Pol-Scopeの場 合はきちんとした画像にならない. 逆に教科書の基本 どおりに行えば何も難しいことはない. また, 上記 $2 の$ 対物レンズの「芯出し」は,レボルバーの種類によって はできない. 芯出しできない場合は, レボルバーの精度 が重要であろう.

細胞運動を微速度記録する場合は, 一定の時間間隔で 原画像を記録する. データ取得時には, モニター上に Pol-Scopeの画像 (リタデーションのマップ) ではな く, 従来の偏光顕微鏡と同樣の画像が表示され, 高検出 能で観察できない. このため, 細胞内部の微細構造は, 原 画像の取得時にモニター上で確認できない. あらかじ め画像を試し撮りし, どこに見たい構造があるのかを 把握し, 兴のうえで, 微速度撮影の間を通じて, 見たい構 造があると思われる位置にピントが合うように補正を 続ける. このピント合わせが, きれいな微速度画像を撮 影するための重要な要素の1つである.

この小文では, 細かな問題点も指摘したので, 操作が 
難しいという印象を受けた方がるかもしれない. しか し, このPol-Scopeの実際の操作は, 光れほと難しくはな い. 筆者の手元のシステムではまったくの初心者でもき ちんと訓練すれば, 2 , 3日できちんとした画像力撮影で きる. (共著者の吉田は, 顕微鏡の操作経験がほとんどな かったが, 実質的に数日で操作を会得し, Fig.1のmovie を撮影した.)

\section{7 .Pol-Scope の観察対象}

Pol-Scope は, 生体試料に限らず, 従来の偏光顕微鏡で 観察対象となるすべての試料を観察できる. 材料科学, 半導体, 結晶学など偏光顕微鏡が使われる広い分野で 使用可能であろう.

医学生物学に限ると, 成長円錐のアクチン束の動態観 察 ${ }^{3)}$ 10), 微小管の定量 ${ }^{11)}$, 12) などの基礎研究や, 人工授 精に適した未受精卵を透明層や紡錘体などの複屈折で 判別できるという臨床応用 ${ }^{13)}$, 14) がPol-Scopeでなされ ている. ブラウン大学のKeefe は人工授精への応用を精 力的に行っている.

今後の可能性だが, Pol-Scopeの開発者のOldenbourg は, 3D デコンボルーションを進めている. 点像分布関数* (PSF) を元に, 計算で光学的切片を求めるのである. 成 功すれば, 厚みがある試料も対象になり, 用途は飛躍的 に広がるだろう. またPol-Scopeには, 光学的にも改善 の余地がある. Oldenbourgは「蜂の巣」のように, 複数 の領域に分かれた液晶を制御し, 電気制御のレクティ ファイアーの機能を含めたPol-Scope の開発を進めて いる. 検出能はさらに高まるかもしれない. また, 我々 は. Pol-Scope と蛍光を組み合わせ, 偏光て細胞構造を, 蛍光て特定のタンパク質の動きを観察できるシステム をつくり,データ取得を始めている.
謝 辞

この研究に用いた新しい偏光顕微鏡を産総研に設置 するにあたり, NEDO「平成 12 年度即効型産業技術助 成事業」の助成をいただいた. 害際のバイオの研究の立 ち上げにあたり科学技術振興事業団から助成をいただ いた. ここに感謝の意を表する.

\section{文 献}

1) Oldenbourg, R. and Mei, G. (1995) J. Microsc. 180, 140-147.

2) Oldenbourg, R. (1996) Nature 381, 811-812.

3) Katoh, K., Hammar, K., Smith, P. J. S. and Oldenbourg, R (1999) Mol. Biol. Cell. 10, 197-210.

4) Hecht, E. (1998) Optics, Addison Wesley Longman Inc. Reading, MA, USA.

5) 鶴田匡夫 (1984) 光の鉛筆, pp.186-196, 新技術コミュ ニケーションズ.

6) 佐藤英美 (1991) 限界を超える生物顕微鏡 (宝谷紘 一, 木下一彦編), pp.31-51, 学会出版センター.

7) 久保田 広 (1959) 応用光学, pp.146-173, 岩波全書.

8) Inoue, S. (1986) Videomicroscopy (1 $1^{\text {st }}$ ed.), Plenum Press, New York.

9) Liu, L., Oldenbourg, R., Trimarchi, J. R. and Keefe, D. L. (2000) Nature Biotechnol. 18, 223-225.

10) Katoh, K., Hammar, K., Smith, P. J. S. and Oldenbourg, R. (1999) Proc. Natl. Acad. Sci. USA 96, 7928-7931.

11) Tran, P., Salmon, E. D. and Oldenbourg, R. (1995) Biol. Bull. 189, 206.

12) Oldenbourg, R., Salmon, E. D. and Tran, P. T. (1998) Biophys. J. 74, 645-654.

13) Keefe, D., Tran, P., Pellegrini, C. and Oldenbourg, R. (1997) Hum. Reprod. 12, 1250-1252.

14) Wang, W. H., Meng, L., Hackett, R. J., Oldenbourg, R. and Keefe, D. L. (2002) Fertil. Steril. 77, 1274-1277.

加藤 薰( かとう かおる)

独立行政法人 産業技術忩合研究所 脳神経情報研究部門主任研究員

科学技術振興機構さきがけ2 21 研究員兼任

連絡先 : ₹ 305-8568 つくば市梅園1-1-1中央第2

E-mail: k-katoh@aist.go.jp

吉田史子(よしだ ふみこ)

(旧所属) 独立行政法人 産業技術総合研究所 脳神経情報研究部門 テクニカルスタッフ

連絡先 : 个 305-8568 つくば市梅園1-1-1中央第2 (在英) 